Article

\title{
Carbon Pricing in the US: Examining State-Level Policy Support and Federal Resistance
}

\author{
Easwaran Narassimhan ${ }^{1,2, *}$, Stefan Koester ${ }^{3}$, and Kelly Sims Gallagher ${ }^{2}$ \\ 1 John F. Kennedy School of Government, Harvard University, USA \\ 2 The Fletcher School, Tufts University, USA \\ ${ }^{3}$ Information Technology and Innovation Foundation, USA \\ * Corresponding author (easwaran_narassimhan@hks.harvard.edu)
}

Submitted: 31 August 2021 | Accepted: 17 December 2021 | Published: 17 March 2022

\begin{abstract}
Carbon pricing is a key policy instrument used to steer markets towards the adoption of low-carbon technologies. In the last two decades, several carbon pricing policies have been implemented or debated at the state and federal levels in the US. The Regional Greenhouse Gas Initiative and the California cap-and-trade policy are the two regional policies operational today. While there is no federal policy operational today, several carbon pricing proposals have been introduced in Congress in the last decade. Using the literature on interest group politics and policy entrepreneurship, this article examines the carbon pricing policies at the subnational and federal levels in the US. First, the article explores the evolution of two main regional carbon pricing policies, the Regional Greenhouse Gas Initiative and California cap-and-trade, to identify how interest groups and policy entrepreneurs shaped the design and implementation of the respective policies. Second, the article details the federal carbon pricing policy proposals and bills discussed in the last decade. Third, it examines the factors that limit the prospects of realizing an ambitious federal carbon price for pursuing deep decarbonization of the US economy. The article finds that federal carbon pricing in the US suffers from the lack of any natural and/or consistent constituency to support it through policy development, legislation, and implementation. While interest group politics have been mitigated by good policy entrepreneurship at the subnational level, the lack of policy entrepreneurship and the changing positions of competing interest groups have kept a federal carbon pricing policy from becoming a reality.
\end{abstract}

\section{Keywords}

allowance allocation; cap-and-trade; carbon price; carbon tax; clean energy standard; deep decarbonization; green new deal; interest group politics; policy entrepreneurship; revenue allocation

\section{Issue}

This article is part of the issue “Carbon Pricing Under Pressure: Withering Markets?" edited by Jørgen Wettestad (Fridtjof Nansen Institute) and Lars H. Gulbrandsen (Fridtjof Nansen Institute).

(C) 2022 by the author(s); licensee Cogitatio (Lisbon, Portugal). This article is licensed under a Creative Commons Attribution 4.0 International License (CC BY).

\section{Introduction}

Since the establishment of the United Nations Framework Convention on Climate Change in 1992, many countries have implemented climate mitigation policies to promote the innovation, production, and consumption of clean energy technologies. Several countries favor market-based policy instruments such as carbon pricing to decarbonize their energy systems. As of
2020, more than 40 national and 20 subnational jurisdictions worldwide have priced carbon explicitly by implementing emissions trading systems (ETS) or carbon taxes (World Bank, 2021). The world is, however, replete with less stringent carbon pricing systems, in which price signals are not high enough to trigger the structural transitions necessary to limit global temperature rise to the $1.5^{\circ} \mathrm{C}$ agreed in Paris. The average global price on carbon among countries with an explicit carbon pricing policy 
stands at just \$2 per ton of greenhouse gas (GHG) emissions (World Bank, 2021). Besides, the mere existence of a carbon price is being used as an excuse by fossil-fuelbased business interests to remove other regulatory and fiscal policies that play a crucial role in decarbonizing an economy (Markard \& Rosenbloom, 2020).

In this context, the article discusses how interest groups and policy entrepreneurs shape the likelihood and stringency of a carbon pricing policy, with examples drawn from the US experience. The article explores how the alignment or misalignment among business and environmental interest groups, and the extent or lack of policy entrepreneurship, shapes the likelihood of implementing a new carbon pricing policy or increasing the stringency of an existing carbon pricing policy at the federal and state level in the US. This article first provides an overview of how interest groups and policy entrepreneurs shaped the two most established subnational carbon pricing systems, the California cap-and-trade program, and the US Northeast Regional Greenhouse Gas Initiative (RGGI). Second, it assesses the role of interest groups and policy entrepreneurs around other carbon pricing proposals introduced at the federal level in the US but not enacted. Third, the article compares how similar interest groups shape policy outcomes differently at the subnational and federal levels. Finally, the article discusses the prospects for a federal carbon pricing policy under the current Biden administration and for deep decarbonization of the US economy.

\section{Theory and Methodology}

Scholars have looked at the political economy factors that determine a polity's choice between a carbon tax and an ETS (Skovgaard et al., 2019; Steinebach et al., 2021) and the design elements that help build public support for a specific carbon pricing instrument (Drew, 2010; Raymond, 2019). Scholars have also emphasized the policy traditions and political history that shape climate policy in a country (Anderson et al., 2020; Wettestad \& Gulbrandsen, 2017). Few studies, however, have looked at how various "political forces" shape the prospect and evolution of carbon pricing policies (Ike, 2020; Jevnaker \& Wettestad, 2017; Markard \& Rosenbloom, 2020; Meckling, 2011; Rabe, 2016; Skocpol, 2013). This article contributes to this growing literature by studying various carbon pricing policies and proposals at the subnational and federal levels in the US.

"Political forces" in climate policy comprise various business and environmental "interest groups," climate "policy entrepreneurs," and "veto actors" with the power to push or pull a policy through the policy-making process. The literature on "interest groups" generally considers business interests to be more cohesive and influential than environmental interests, perhaps due to their role in the economy and their potential to create value and employment (Jevnaker \& Wettestad, 2017). Markard and Rosenbloom (2020) use the European Union (EU)
ETS to show that business interests are also divided and actively struggling to decide the course of climate policymaking. Jevnaker and Wettestad (2017) argue that EU ETS reform became possible primarily due to differing positions among business interests and alliances between members of the business community and policy entrepreneurs. Rabe (2016) argues that RGGI's success was primarily attributable to the expertise and efforts of "policy entrepreneurs" who seized political opportunities to implement the program and ensured that program benefits reached multiple business and environmental "interest groups." Nevertheless, Ike (2020) shows how a small cohesive set of "veto actors" were able to dismantle Australia's carbon tax policy.

Comparing the efforts to pass the Waxman-Markey cap-and-trade bill with the comprehensive healthcare reform bill in the US, Skocpol (2013) argues that the lack of an advocacy group to mobilize support for the cap-andtrade policy was the main reason for its failure to pass in Congress. By studying several carbon pricing policies and proposals over time, we find that while many advocacy groups have emerged and supported various carbon pricing proposals in Congress since Waxman-Markey, the constellation of supportive actors has been inconsistent over time. While the constantly changing interest group politics have been managed by good policy entrepreneurship at the subnational level, a lack of this policy entrepreneurship, combined with the increasing complexity of interests within and between different interest groups, has kept a carbon pricing policy from becoming reality at the federal level in the US.

We conduct a document analysis of academic articles, government reports, and media mentions of carbon pricing policies and bill proposals in the US to identify the constellation of interest groups that support or oppose a particular policy or bill proposal and how well policy entrepreneurs have managed interest group politics to implement carbon pricing at the subnational and federal level. We also look at public statements and reports by industry and environmental groups to assess their support or opposition to a carbon pricing policy or proposal. We use Wilson's typology of optimal policymaking to explain how interest groups and policy entrepreneurs shape the likelihood of a carbon pricing policy at the subnational and federal levels in the US. Wilson's typology of optimal policymaking defines the conditions under which various political forces influence policymaking (Wilson, 1980; see Table 1). When the cost of a policy is dispersed, it leads to client politics or majoritarian politics depending on whether the benefits of a policy are concentrated or dispersed, respectively. However, when the cost of a policy is concentrated, it gives rise to interest group politics and entrepreneurial politics depending on whether the benefits are concentrated or dispersed.

Scholars have argued that the cost of a carbon pricing policy is often concentrated on specific industries based on their: (a) "asset specificity" (i.e., industries 
Table 1. Reinterpretation of Wilson's typology.

\begin{tabular}{ccc}
\hline & & \multicolumn{2}{c}{ Cost of Regulation } \\
\cline { 2 - 3 } Benefits of Regulation & Concentrated & Dispersed \\
\hline $\begin{array}{c}\text { Concentrated } \\
\text { Dispersed }\end{array}$ & interest group politics & client politics \\
entrepreneurial politics & majoritarian politics \\
\hline
\end{tabular}

Source: Wilson (1980).

that have invested in durable physical assets and natural resource endowments; Jenkins, 2014), and (b) emissions intensity and exposure to trade (Aldy \& Pizer, 2015). In addition, such industries in the US are concentrated in specific regions (Broekhoff et al., 2021) giving rise to region-specific interests and politics (Skocpol, 2013). While some industries pass the cost on to the consumer in the form of higher prices for goods (Jenkins, 2014), emissions intensive and trade exposed (EITE) firms lose market share to international competitors who operate in a jurisdiction without a carbon price (Aldy \& Pizer, 2015). Nevertheless, scholars have shown that EITE firms can also disperse their costs with the help of supplementary policies (Dobson \& Winter, 2018). While protection for EITE firms may be warranted due to the legitimate concerns of carbon leakage (Dobson \& Winter, 2018), policy design calibrations and supplementary policies arise from policy entrepreneurs engaging with different industry stakeholders over time, making the Wilson typology an appropriate framework for studying how interest groups and policy entrepreneurs work together to shape policy design and implementation. While interest groups attempt to get economic benefits in return for the policy costs incurred, policy entrepreneurs help direct the economic benefits of a carbon pricing policy through policy design calibrations such as the creation of specific allowance allocations and redistribution of revenue to certain actors, thereby weakening the cohesion of interest groups and stimulating the emergence of diverse interests (Patashnik, 2014; Wilson, 1980).

\section{Carbon Pricing in the US}

This section first introduces the two subnational carbon pricing policies in the US and then evaluates the attempts to implement federal carbon pricing legislation over the last three decades.

\subsection{Regional Greenhouse Gas Initiative}

RGGI, the first cap-and-trade policy in the US for regulating carbon dioxide $\left(\mathrm{CO}_{2}\right)$ emissions, covers power sector $\mathrm{CO}_{2}$ emissions in eleven northeastern states-Connecticut, Delaware, Maine, Maryland, Massachusetts, New Hampshire, New York, New Jersey, Rhode Island, Vermont, and Virginia. RGGI is a good example of gubernatorial policy entrepreneurship in the US (Biedenkopf, 2017). In 2003, then Governor George Pataki of New York invited his counterparts from northeastern states to discuss the possibility of curbing $\mathrm{CO}_{2}$ emissions (Regional Greenhouse Gas Initiative [RGGI], 2021a). Discussions between the states and subsequent negotiations with public and private stakeholders led to signing a Memorandum of Understanding (MOU) between the original seven northeastern states in December 2005 to secure respective state legislative and regulatory approvals for a regional cap-and-trade program (RGGI, 2021b).

\subsubsection{Program Design}

RGGI set a goal of stabilizing $\mathrm{CO}_{2}$ emissions from the power sector at 2009 levels (based on the modelling assumptions made in 2005) through 2014 and reducing emissions by 10 percent ( 2.5 percent every year) by 2019 (Kretzschmar \& Whitford, 2012). In 2006, environmental agency officials from various RGGI states reached an agreement to ensure that each state auction at least 25 percent of its allocation of emission allowances. Allowances were distributed through quarterly auctions conducted in a sealed-bid and uniformprice format (International Carbon Action Partnership [ICAP], 2021a). To avoid bidder collusion and ensure revenue generation, RGGI set a reserve price of $\$ 1.86$ in 2008, increasing it to \$2.26 in 2019 (Kretzschmar \& Whitford, 2012). Allowance holders were allowed to bank them for future use, and no single party was allowed to purchase more than 25 percent of emission allowances in a single auction to avoid potential market manipulation. In a show of gubernatorial entrepreneurship in 2006, Governor Pataki decided to auction 100 percent of New York's allowances, motivating other RGGI state legislatures to endorse the full auctioning of emission allowances before beginning the first auctions in September 2008 (Huber, 2013). Between 2008 and 2019, RGGI states sold about 80 percent of the emission allowances through 44 auction rounds, generating more than $\$ 3.2$ billion in revenue and retired the unsold allowances (Ramseur, 2019).

RGGI policy entrepreneurs exploited the cleavages within the US power sector interest groups and introduced allowance auctioning. While power generation companies complained that auctioning would impose a substantial cost on them and pushed for grandfathering of allowances, restructured investor-owned utilities like National Grid supported the sale of allowances, with proceeds from the sale benefiting consumers through electricity bill rebates or other means (Cook, 2010). 
RGGI policy entrepreneurs decided to allocate the auction revenues to improve energy efficiency, mitigate ratepayer impacts, and promote renewable technologies (ICAP, 2021a). This garnered the support of environmental interest groups, who were often searching for state funds to support energy efficiency improvement initiatives (Huber, 2013). Besides, large industrial users of electricity that were not regulated under RGGI liked the idea of benefiting from energy efficiency programs, even if their electricity rates increased.

\subsubsection{Program Evolution and Politics}

Since the program's start in January 2009, RGGI policy design has changed little, except for the 44 percent cap reduction for the 2014-2030 trading period (from 165 to $91 \mathrm{mtCO}_{2}$ relative to 2012 emission levels) to account for the reduction in demand from energy efficiency improvements and the economic recession of 2009 (Narassimhan et al., 2018). While RGGI has operated for more than a decade without significant changes to its design, there have been uncertainties in terms of subscription. Driven by state-level partisan politics, states have moved in and out of the program, highlighting the vulnerability of a voluntary regional cap-and-trade program with a legal basis residing in the respective states. Policy entrepreneurship motivated by political ideology, however, has brought states back into RGGI. In 2005, Massachusetts left RGGI despite signing the MOU. Republican Governor Mitt Romney directed the state's environmental regulators to develop a stand-alone cap-and-trade policy instead (Cook, 2010). Subsequently, Democratic gubernatorial candidate Deval Patrick used RGGI as a wedge issue in the 2006 elections and brought back Massachusetts into RGGI in January 2007 after becoming governor (Bausch \& Cavalieri, 2007). New Jersey and New Hampshire faced significant interest group pressure, specifically from electric power generators opposing the full auctioning of emission allowances, with state legislative votes on the issue being far more contentious and closer than in any other state joining RGGI (Huber, 2013). In 2011, Republican Governor Chris Christie of New Jersey pulled the state out of RGGI, forcing RGGI to temporarily reduce the emissions cap (RGGI, 2021c). After nine years, Democratic Governor Phil Murphy reenrolled New Jersey in RGGI in 2020, with a 30 percent reduction in the overall cap for the state from 2020 to 2030 (Center for Climate and Energy Solutions, 2021). Finally, Maine's Republican Governor and the state legislature passed legislation that would remove the state from the program if most member states exited (Huber, 2013).

The Trump administration's reversal of federal climate policies also motivated more states to take climate action at the subnational level. In 2020, Virginia enacted the Virginia Clean Economy Act and directed its state pollution control board to adopt RGGI regulations to create a cap-and-trade policy. Similarly, Democratic Pennsylvania Governor Tom Wolf directed the Pennsylvania Department of Environmental Protection to pass a rule that will enable the state to join RGGI in 2022 (Bell \& Mallinson, 2021). The Republican state legislature has condemned the governor for executive overreach as well as indifference towards the livelihoods of Pennsylvania citizens (Bell \& Mallinson, 2021), indicating the risk involved in a policy pathway that relies upon executive branch regulatory authority and could be overturned should the governorship change parties.

Finally, while RGGI is expanding its geographical coverage, state-level electoral politics continue to constrain its ability to increase the stringency of the emissions cap or expand coverage to other GHG emitting sectors. The prevailing carbon price of $\$ 8.38$ per ton of $\mathrm{CO}_{2}$ emissions is just one-sixth of the $\$ 51$ per ton social cost of carbon at a 3 percent discount rate in 2020 as recommended by the current US government to justify the costs and benefits of climate regulations (Chemnick, 2021). Despite low prices, $\mathrm{CO}_{2}$ emissions from the electricity sector in the RGGI states have fallen 60 percent between 2009 and 2021, perhaps due to the long-term policy signal created by the ETS and recycling of auction revenues to finance energy efficiency programs. Other complementary policies to promote energy efficiency and low-carbon investments have likely also played a significant role (Murray \& Maniloff, 2015). Nevertheless, the long-term policy signal created by the RGGI establishment seems to have convinced stakeholders in the region that decarbonization was inevitable, so highcarbon power plants have consistently been replaced by lower-carbon alternatives.

\subsection{California Cap-and-Trade Program}

The cornerstone of California's almost two-decade-long efforts to reduce economy-wide GHG emissions is the state's cap-and-trade program. Since the program's inception in 2012, it has undergone numerous regulatory and legislative changes that have expanded and altered the program's scope. These changes have largely been in response to business, environmental justice, and community stakeholder lobbying (Bang et al., 2017). The enabling legislation for the program is the state's Global Warming Solutions Act (Assembly Bill [AB] 32), passed in 2006 and signed by Republican Governor Schwarzenegger, requiring California to reduce emissions to 1990-levels by 2020 (California Global Warming Solutions Act of 2006, 2006).

\subsubsection{Program Design}

The program has a declining annual cap on covered emissions, covering roughly 80 percent of the state's GHG emissions. It has expanded over each compliance period to include additional GHG sources, with downward revisions in the cap, the implementation of various price controls, and changes to offset certification practices. The first pilot compliance period began in 2013 and 
covered 36 percent of the state's overall emissions from large industrial facilities, large stationary combustion sources, $\mathrm{CO}_{2}$ suppliers, in-state electricity generators, and, notably, imported electricity (ICAP, 2021b). This early decision to cover imported electricity, which was 45 percent of the state's electricity emissions at the time, was the first and only instance to date of a cross-border carbon adjustment mechanism (California Air Resources Board [CARB], 2021a). Subsequent compliance periods have expanded the scope of covered economic sectors to include natural gas suppliers and fuel and petroleum suppliers, and today covers roughly 500 entities. With competitiveness concerns and pressure from industry interest groups (Schmalensee \& Stavins, 2017) and despite the opposition of environmental NGOs (Climate Hawks, 2017), policy entrepreneurs used a hybrid approach of allowance allocation with free allowances for EITE industrial facilities. Allowances are allocated freely to industrial facilities on an adjusted basis depending on their leakage risk, a function of a firm's emissions intensity and trade exposure. Total free industrial allowance allocation has declined through each subsequent compliance period but represented 31 percent of 2021 allowances (CARB, 2021b). Electric distribution utilities and natural gas suppliers make up the remainder of allowances, receiving free allowances that must be auctioned on behalf of ratepayers and used for emission reduction activities. The program has generated proceeds of $\$ 15.8$ billion (CARB, 2021c) that have been allocated to numerous state environmental, transportation, and air quality improvement projects (California Climate Investments, 2019).

\subsubsection{Program Evolution and Politics}

The program has undergone several legislative revisions because of interest group politics. It has been subject to both state and federal lawsuits challenging its legality. Early state lawsuits sought to invalidate the law, claiming that the auctioning of allowances by the California Air Resources Board (CARB) was an illegal tax, due to a state requirement that new state taxes require a two-thirds legislative vote, and that the program's enabling legislation did not give them the authority to implement the cap-and-trade program. This lawsuit failed, with plaintiffs ultimately appealing to the state Supreme Court in June 2017, which declined to review previous state appellate court decisions, holding that the cap-and-trade program was legal and that auctioning of allowances did not represent an illegal tax (California Case Chart, 2021).

In 2017 , the program was significantly altered with the passage of $A B 398$ by a two-thirds supermajority vote in the California legislature, which included Republican support. CARB and state legislators successfully conducted political negotiations among business groups, environmental justice organizations, and other stakeholders to design AB 398 (Arrieta-Kenna, 2017). Notably, groups that had opposed the program in the past, such as oil and gas industry groups, came out in support of $A B$ 398, while over 50 environmental justice and progressive economic justice groups opposed the bill's continued reliance on free allowances and preemption of local air quality regulatory control (Climate Hawks, 2017; Mason \& Megerian, 2017). AB 398 extended the program through 2030 , providing greater market certainty. In recognition of the controversial nature of carbon offsets, the bill lowered the offset cap from 8 percent of compliance obligation to 4 percent between 2021 and 2025 and 6 percent from 2026 onward. The legislation required that no more than 50 percent of offsets come from projects that do not have a direct environmental benefit within California (California Global Warming Solutions Act of 2006, 2017). These qualitative changes to the types of offsets allowed represent a significant political victory for state environmental justice groups that argued that out-of-state offsets allowed for continued air emissions and environmental justice degradation in the state (California Environmental Justice Alliance, 2017). Business and oil interest groups lobbied successfully for benefits as well. The bill allowed for the continuation of free allowances, included provisions for businesses to preempt local air district regulation of GHGs, and limited the ability to regulate GHG emissions from oil refining to within the cap-and-trade program. The program also implemented an allowance price ceiling, beginning at $\$ 65$ per allowance in 2021, increasing 5 percent annually plus inflation (CARB, 2021d).

Besides pressure from state-level interest groups, the program was challenged by the Trump administration. In May 2012, California had initiated the process to link with Québec's cap-and-trade market beginning in 2014 (CARB, 2021e). This represented the first international linkage between two subnational carbon markets, with the partners overcoming linguistic, regulatory, and national differences. The Trump administration, however, sued California in the US District Court for the Eastern District of California, claiming that the linkage between California and Québec was an attempt by the state to pursue independent foreign policy and was thus unconstitutional (US Justice Department, 2019). The US District Court rejected the government's argument in March 2020, finding that the linkage agreement between California and Québec was not a treaty and did not violate the Treaty or Compact clauses of the Constitution, further ensuring the viability of the program (US Justice Department, 2020).

While it is difficult to disaggregate state-wide emission reductions that result from the state's cap-andtrade program and other state policies, total emissions declined by 5.3 percent during the program's first compliance period between 2013 and 2017 (CARB, 2019). The lack of impressive reductions can be attributed to the fact that the electricity sector was already decarbonizing due to regulatory policies, including the first moratorium on new coal fired power plants and California's policies to support in-state renewable 
power generation (California Energy Commission, 2021; California Legislative Information, 2005). On the other hand, the industry and transport sectors continue to be less sensitive to status quo carbon prices because technological alternatives such as green hydrogen for industries (Ball \& Weeda, 2015) and electric vehicles for transport (Breetz \& Salon, 2018) are not price competitive with their fossil fuel counterparts.

\subsection{Federal Carbon Pricing Initiatives}

\subsubsection{Early Attempts at a Federal Carbon Price}

The most successful application of market-based pollution pricing in the US was the cap-and-trade system to regulate $\mathrm{SO}_{2}$ emissions established under the US Clean Air Act Amendments of 1990 (Stavins, 2008). The program created a robust market for $\mathrm{SO}_{2}$ allowance trading and helped reduce $\mathrm{SO}_{2}$ emissions by 94 percent between 1990 and 2005 (15.7 to 0.95 million tons; Environmental Protection Agency, 2019). Yet, attempts at implementing a pricing mechanism for $\mathrm{CO}_{2}$ emissions have bedeviled policymakers for more than three decades. The first carbon tax bill was introduced in 1990 after the Intergovernmental Panel on Climate Change's First Assessment Report and faced bipartisan opposition, with some arguing that the data and science of global climate change were yet unsettled (US House of Representatives, 1990). Since then, more than 50 distinct pieces of carbon pricing legislation have been introduced in Congress. Efforts to craft bipartisan carbon pricing legislation picked up momentum in the wake of President George W. Bush's decision not to implement the Kyoto Protocol. In both the 108th (2003-2004) and 109th (2004-2005) Congress, there were numerous bipartisan efforts to pass a national economy-wide capand-trade system, but none gained significant traction.

With the election of President Obama in 2008, Congressional efforts to create a federal cap-and-trade policy picked up steam (see Figure 1). The House American Clean Energy and Security Act, widely known as the Waxman-Markey cap-and-trade bill (see Table 2), successfully passed the House in June 2009 but failed to pass in the Senate due to insufficient support. The House bill passed by just seven votes, garnering eight Republican votes out of a minority of 179 Republicans. But 44 Democrats voted against the bill out of a majority of 255 Democrat representatives. Besides the lack of an advocacy group to promote the bill (Skocpol, 2013), Congressional Democratic leadership and President Obama failed to navigate multiple interest groups successfully. Experts criticized the White House for failing to engage more forcefully in the legislative politics seen as necessary to passing landmark legislation (Lizza, 2010).

Electricity industry groups such as the Edison Electric Institute came out in support of the legislation, as did large utilities such as Duke Energy and chemical maker DuPont (Weiss \& Wagener, 2009), while environmen- tal groups such as Greenpeace opposed it because of its free allowance allocation, among other concerns (Greenpeace, 2010). The bill included several carve-outs, concessions, and subsidies to fossil and electricity interest groups (Broder, 2009). Free allowances made up more than 85 percent of the total allocation through 2026, leading President Obama's budget director at the time to remark that the bill represented "the largest corporate welfare program that has ever been enacted in the history of the United States" (Wessel, 2009). Despite several concessions, traditional business trade organizations, most notably the National Association of Manufacturers, the US Chamber of Commerce, and the Business Roundtable, and fossil fuel industry trade groups, including the American Petroleum Institute and American Gas Association, came out in strong opposition to the Waxman-Markey bill (Union of Concerned Scientists, 2013). Labor groups, such as the United Mine Workers Association, who lobbied for carve-outs in the House bill, ended up opposing the bill in the Senate (American Federation of Labor and Congress of Industrial Organizations, 2009).

\subsubsection{Subsequent Federal Carbon Pricing Attempts}

Subsequent Federal Carbon Pricing Attempts After the failure of Waxman-Markey, the Obama administration shifted towards regulatory policies implementable through executive authority granted under laws, most specifically the Clean Air Act (Reilly \& Bogardus, 2016). Obama's tactical shift to a regulatory approach and the increasing public support for climate action induced a few Republicans to reevaluate their opposition to marketbased policies such as carbon pricing. In 2017, two former Republican secretaries of state, James Baker and George Shultz, launched the Climate Leadership Council, an advocacy organization calling for a carbon tax of $\$ 43$ per ton to halve US GHG emissions by 2035 , with revenue recycled back to citizens in the form of a carbon dividend (Table 2). The proposal also includes provisions to simplify the existing Environmental Protection Agency's regulatory authority and to impose a carbon border adjustment tax to protect vulnerable EITE industries.

Congressional efforts have continued since, with 15 separate bills introduced during the 115th (2017-2019), 116th (2019-2021), and 117th (2021-2023) Congressional terms, with four bills having both Democrat and Republican co-sponsorship (see Table 2 for the most discussed bills with supporting and opposing interest groups identified; see the Supplementary Material for all bills introduced during the 115th 116th, and 117th Congressional terms; Hafstead, 2021). Table 2 builds on Hafstead (2021) data to identify business and environmental interest groups that support or oppose these federal carbon pricing bill proposals by looking for reports or public statements made by them. Almost all of these bills are carbon taxes but differ in their stringency and allocation of revenue. 
Public interest in carbon taxes is evident from the Google search interest spiking around 2016 for the term "carbon tax" (see Figure 1). It is possible that given the failure of the Waxman-Markey cap-and-trade legislation or because of the inherent complexities and avenues for political rent-seeking in cap-and-trade programs, only a tax-based carbon pricing mechanism is seen as politically viable. A notable feature of all recent carbon tax proposals is the inclusion of carbon border adjustments. Scholarly evidence shows that carbon leakage is

Table 2. Subnational and federal carbon pricing policies in the US.

\begin{tabular}{|c|c|c|c|c|}
\hline $\begin{array}{l}\text { Policy/Bill Name; } \\
\text { Policy Type; } \\
\text { Year started }\end{array}$ & $\begin{array}{l}\text { Prevailing or } \\
\text { Proposed } \\
\text { Price/ton GHG) }\end{array}$ & $\begin{array}{l}\text { Policy } \\
\text { Entrepreneurs }\end{array}$ & $\begin{array}{l}\text { Interest } \\
\text { Groups }\end{array}$ & $\begin{array}{l}\text { Allowances and } \\
\text { Revenue Use }\end{array}$ \\
\hline \multicolumn{5}{|c|}{ Subnational Policies } \\
\hline $\begin{array}{l}\text { - RGGI } \\
\text { - Cap-and-trade; } \\
2009\end{array}$ & $\$ 8.38$ & $\begin{array}{l}\text { Policy experts from } \\
\text { state-level } \\
\text { environment } \\
\text { departments; } \\
\text { State Governors. }\end{array}$ & $\begin{array}{l}\text { - Support: Power } \\
\text { utilities; non-power } \\
\text { industry groups; } \\
\text { environmental NGOs. } \\
\text { - Opposition: Power } \\
\text { generators. }\end{array}$ & $\begin{array}{l}\text { - } 100 \text { percent allowance } \\
\text { auctioning. } \\
\text { - Revenue used for } \\
\text { energy efficiency, } \\
\text { clean energy projects, } \\
\text { and ratepayer benefits. }\end{array}$ \\
\hline $\begin{array}{l}\text { - California } \\
\text { cap-and-trade } \\
\text { - Cap-and-trade; } \\
2013\end{array}$ & $\$ 17.80$ & $\begin{array}{l}\text { CARB; State } \\
\text { legislators. }\end{array}$ & $\begin{array}{l}\text { - Initial support and } \\
\text { subsequent opposition: } \\
\text { Environmental justice } \\
\text { and protection NGOs. } \\
\text { - Initial opposition and } \\
\text { later support: Oil and } \\
\text { gas industry groups, } \\
\text { power generators } \\
\text { and utilities. }\end{array}$ & $\begin{array}{l}\text { - } 70 \text { percent auctioning. } \\
\text { - Revenue used for clean } \\
\text { energy R\&D, } \\
\text { manufacturing, rebates } \\
\text { to low-income } \\
\text { communities. }\end{array}$ \\
\hline
\end{tabular}

Federal Proposals and Bills

\begin{tabular}{|c|c|c|c|c|}
\hline $\begin{array}{l}\text { - Waxman- } \\
\text { Markey } \\
\text { cap-and-trade } \\
\text { bill } \\
\text { - Cap-and-trade; } \\
2009\end{array}$ & $\mathrm{~N} / \mathrm{A}$ & $\begin{array}{l}\text { Congressmen } \\
\text { Markey and } \\
\text { Waxman. }\end{array}$ & $\begin{array}{l}\text { - Support: Electricity } \\
\text { industry groups. } \\
\text { - Opposition: Oil and gas } \\
\text { industry groups; } \\
\text { environmental NGOs. }\end{array}$ & $\begin{array}{l}85 \text { percent free } \\
\text { allowances until } 2026 \text {. }\end{array}$ \\
\hline $\begin{array}{l}\text { - Climate } \\
\text { Leadership } \\
\text { Council } \\
\text { (Proposal; } \\
\text { Not a Bill) } \\
\text { - Carbon tax; } \\
2017\end{array}$ & $\$ 43$ & $\begin{array}{l}\text { Former Republican } \\
\text { Secretaries of State } \\
\text { James Baker and } \\
\text { George Shultz. }\end{array}$ & $\begin{array}{l}\text { - Support: Energy } \\
\text { intensive manufacturers; } \\
\text { electric utilities; some } \\
\text { environmental } \\
\text { organizations. } \\
\text { - Opposition: Center for } \\
\text { Progressive Reform } \\
\text { (CPR) }\end{array}$ & Carbon dividends. \\
\hline $\begin{array}{l}\text { - Energy } \\
\text { Innovation and } \\
\text { Carbon } \\
\text { Dividend Act } \\
\text { - Carbon tax; } \\
2019\end{array}$ & $\begin{array}{l}\text { \$15 starting } \\
\text { in 2020, } \\
\text { increases } \\
\$ 10 / \text { year. }\end{array}$ & $\begin{array}{l}\text { Rep. Deutch (D-FL), } \\
85 \text { Democrat, } \\
1 \text { Republican } \\
\text { co-sponsor. }\end{array}$ & $\begin{array}{l}\text { - Support: Citizens } \\
\text { Climate Lobby; Center } \\
\text { for Climate and Energy } \\
\text { Solutions (C2ES); Trout } \\
\text { Unlimited; Evangelical } \\
\text { Environmental Network; } \\
\text { Business Climate } \\
\text { Council. } \\
\text { - Opposition: Center for } \\
\text { Biological Diversity. }\end{array}$ & Carbon dividends. \\
\hline
\end{tabular}

Note: Refer to the supplementary material for all bills introduced during the 115-117th Congress. Sources: Hafstead (2021), ICAP (2021a, 2021b). 


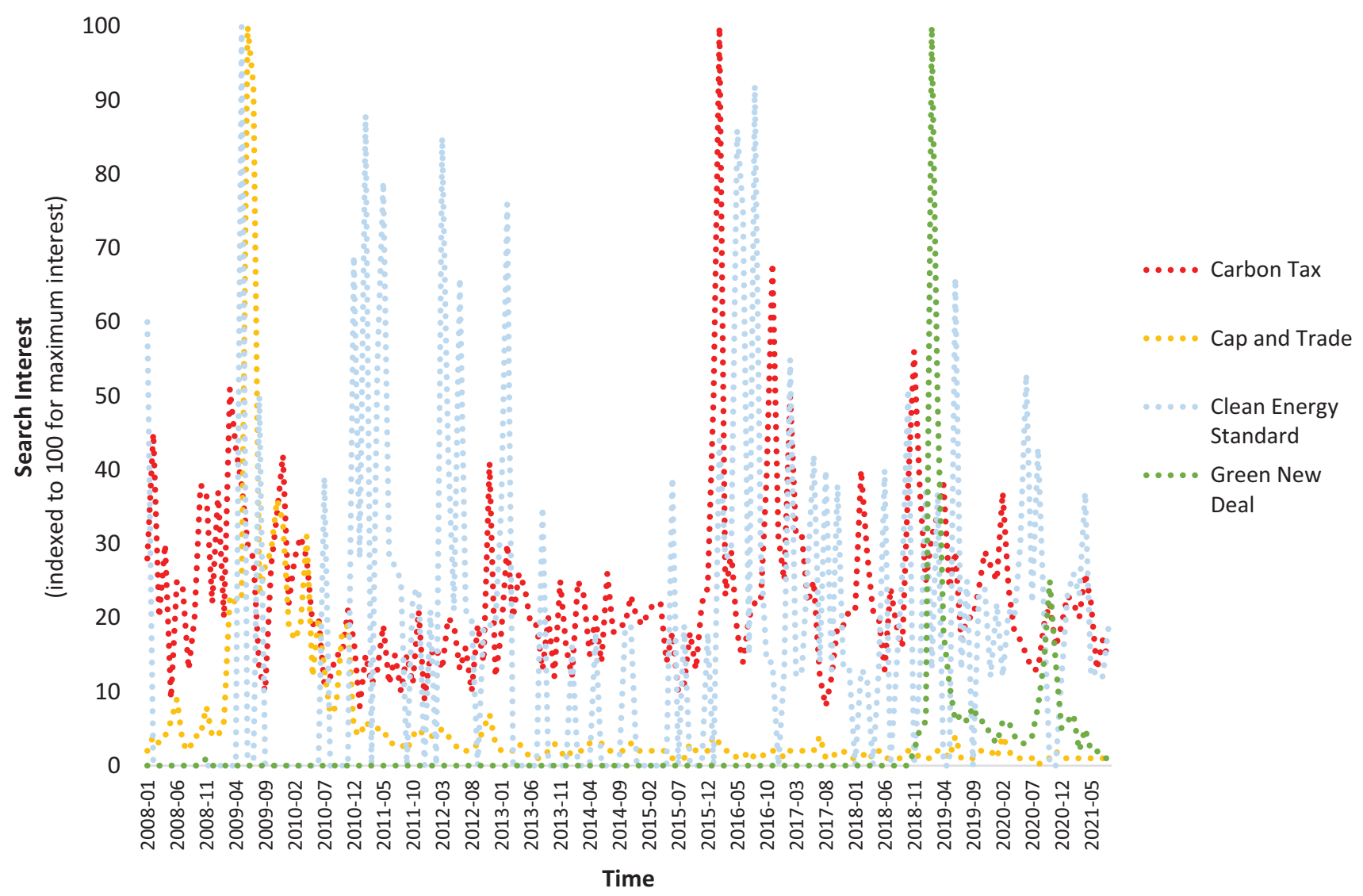

Figure 1. Search interest around key federal policies. Source: Google Trends (n.d.).

a significant problem in jurisdictions with a carbon price (Bushnell \& Chen, 2012; Dobson \& Winter, 2018; Fischer \& Fox, 2012). Providing relief to EITE industries through supportive policies such as carbon border adjustments is seen as a political necessity in all proposed legislation to date (Venmans et al., 2020), indicating how business interests' lobbying to mitigate the cost of carbon pricing policy is met with policy entrepreneurs' legitimate concern for addressing carbon leakage.

\subsubsection{Changing Political Support for Carbon Pricing at the Federal Level}

Support from environmental and business interests has also evolved. In the 2000s, environmental NGOs and the carbon pricing epistemic community, including many academics and environmental think tanks, had strong links. Carbon pricing lobbies like the International Emissions Trading Association, the Citizens Climate Lobby, and the Carbon Markets and Investors Association pushed for aggressive expansion of carbon pricing coverage and reduction in emissions alongside some environmental organizations led by the Environmental Defense Fund (Paterson, 2012). Whereas in the past, environmental groups and Democratic Congressional leaders were likely to see carbon pricing as the linchpin to any national climate strategy, there was a conspicuous absence of any mention of carbon pricing in the nonbinding House Resolution that laid out the framework for the Green New Deal in 2019 (US House of Representatives, 2019). Several environmental justice groups oppose a federal carbon price because they object to the notion that polluters can pay a tax and continue to pollute near low-income minority communities, sometimes referred to as "sacrifice-zones," which already bear the burden of fossil fuel infrastructure (National Association for the Advancement of Colored People, 2021). Environmental advocates also worry that depending on how the policy is implemented, a carbon price can be regressive, disproportionately hurting low-income people (Cronin et al., 2019).

At the dawn of the Biden administration, the politics of carbon pricing underwent yet another shift. Besides a few lone Republican politicians, many more business interests came out in support of a carbon price, fearing that the administration would gravitate towards the Green New Deal and the use of non-market-based regulations such as clean energy standards (CES). A CES is a policy that mandates a minimum amount of electricity to be generated from clean energy resources. Figure 1 shows that interest in CES has increased since 2020. The American Petroleum Institute, the 
Chamber of Commerce, and the Business Roundtable, who all opposed federal carbon pricing policies previously (Meyer \& Neuberger, 2021), now support carbon pricing, with policy caveats such as the removal of federal emission regulatory authority or streamlining permitting requirements. Some commentators note that this offers an opportunity for fossil fuel and traditional business groups to harness their political influence to push for market-based policies (Meyer \& Neuberger, 2021). However, these shifting positions may be either political manipulation or worse, disingenuous policies that are too weak to have significant emissions benefit or have no realistic chance of passing due to the many veto actors in the US legislative process (350.org, 2021). This fear was reinforced in June 2021, when an ExxonMobil lobbyist was caught in a sting operation admitting that the company's support for carbon pricing was largely a political ploy and that a "carbon tax is not going to happen" (McGreal, 2021).

\section{Discussion: State-Level Embrace and Federal Resistance}

This article finds that carbon pricing in the US at the federal level suffers from the lack of a consistent constituency to support it through policy development, legislation, and implementation and faces key veto actors that have consistently managed to block it. While interest group politics have been mitigated by good policy entrepreneurship at the subnational level, the lack of a consistent constituency combined with the increasing complexity of interests at the federal level have kept a carbon pricing policy from becoming a national reality. Moreover, with the shrinking timeline for climate action, interest groups have changed their positions over time and continue to be misaligned with one another when it comes to realizing a federal carbon price or ratcheting up the stringency of existing subnational carbon prices.

\subsection{Policy Entrepreneurship and Interest Group Politics}

The evolution of RGGI shows that policy entrepreneurship played a crucial role, winning over the interest groups with a pragmatic and initially less ambitious carbon pricing policy. RGGI policy entrepreneurs limited the program's policy space to $\mathrm{CO}_{2}$ emissions from the electricity sector, enabling regional expansion. The electricity sector in the northeastern states has common characteristics due to shared power generation and transmission resources. Through active stakeholder engagement across RGGI states, policy entrepreneurs understood the cleavages within the electricity sector (power generators, transmission, and distribution utilities) and other industry groups indirectly affected through higher electricity rates from a carbon price. By auctioning all the emission allowances and mandating the use of auction revenues for ratepayer benefits, energy efficiency programs, and other strategic energy purposes, they ensured the sup- port of residential and industrial consumers as well as environmental interest groups.

Policy entrepreneurship at the gubernatorial level also played a crucial role in keeping the RGGI states in the cap-and-trade system, particularly because RGGI depends on either state-level legislative support or executive environmental and air quality departments. Pennsylvania, for example, is working to join RGGI, but due to Republican majorities in the state legislature, the governor has relied on an executive branch regulatory approach, with Republican lawmakers moving to block the state from joining (Cann, 2021). Nevertheless, RGGI is vulnerable to defections if it tries to tighten the emissions cap or expand its emissions coverage to sectors beyond electricity, limiting the scope of the cap-andtrade regime as it stands today. This challenge is evident from the recent pull out of Connecticut, Massachusetts, and Rhode Island, three states with Democratic legislative leadership, from the Transportation and Climate Initiative, a cap-and-trade-like program proposed for reducing transport sector GHG emissions in the RGGI states (Roberts, 2021).

Unlike RGGI, which covers only the power sector across northeastern states, California took a more ambitious approach by implementing a comprehensive economy-wide cap-and-trade program covering all GHGs. However, the combined power of California's electricity and other industry interest groups meant that it could not capitalize on the divisions between different industry interests as RGGI did. Hence, policy entrepreneurs used a hybrid approach of allowance allocation with free allowances for EITE industries, much to the dismay of environmental NGOs. Nevertheless, the cap-and-trade policy faced several court challenges from business and oil and gas industry groups claiming it was an illegal tax. $A B 398$, the latest legislative update extending the program until 2030, provided significant tax breaks (funded from auction revenues) for industries, including the electricity sector. While environmental justice groups fought to get more rebates for low-income California residents and curb industrial pollution near low-income communities, policy entrepreneurs succumbed to industry pressure in the interest of the long-term stability of an economy-wide cap-and-trade. While this article did not discuss Washington state's failure to implement a carbon tax in 2016 and again in 2018, it was also an example of policy entrepreneurship succumbing to changing interest group politics and advocacy support. While both business and environmental interests opposed the policy in 2016 for its stringency and revenue allocation, respectively, a few businesses and fossil fuel interests derailed it in 2018 (Carbon Tax Center, 2018; Reed et al., 2019).

At the federal level, neither a narrow sector-focused nor an economy-wide carbon price exists today. Unlike RGGI and California, the multiplicity of veto actors at the federal level, such as the requirement for supermajorities in the US Senate to pass legislation to avoid the filibuster, makes the prospects of a carbon pricing policy 
bleak. For instance, the Waxman-Markey cap-and-trade bill, introduced when Democrats held the presidency and majorities in both House and Senate, only narrowly passed in the House and failed to be brought to a vote in the Senate, with then-Senate Majority Leader Harry Reid noting that "it's easy to count to 60 [the required number of votes to overcome the Senate filibuster]...we know we don't have the votes" (Davenport \& Samuelsohn, 2010). The limited success of Democratic policy entrepreneurs to convince members of their party indicates the power of multiple veto actors, as was evident in the cancellation of the carbon tax policy in Australia (Ike, 2020). The multiplicity of interest groups is also an important factor. RGGI and California's industry mix is significantly different from the mid-western and southern states which are more fossil-fuel intensive, making federal politics dominated by more industry interests than environmental groups (Energy Information Administration, 2019). Hence, any environmental legislation at the federal level in the US is likely to be a watered-down version of corresponding subnational efforts.

\subsection{Shrinking Timelines and Misaligned Interests}

Besides the lack of policy entrepreneurship and the multiplicity of interest groups, the priorities of different interest groups have changed over time. Previously aligning themselves as pro- and anti-climate, interest groups now align themselves as pro-climate and climate-indifferent. Industry interest groups have determined that it may be good business to theoretically support a carbon price even if they do not proactively lobby for a carbon tax or cap-and-trade system. When the Waxman-Markey bill was introduced, several industry groups unfamiliar with carbon pricing saw the policy as anti-business. Thanks to the exhaustive scholarship produced by epistemic communities over the last decade, business groups now are more familiar with the policy and understand that it provides more business certainty in the long run and is likely cheaper than complying with regulatory policies. More cynically, the business and fossil fuel industry may also be using carbon pricing as a "Trojan Horse," a strategy to divert attention from, and fend off, more ambitious climate action (Markard \& Rosenbloom, 2020).

While industry interest groups increasingly favor carbon pricing legislation at the federal level, many environmental groups have changed their position to instead support the use of regulations, given the shrinking timeline for climate action. Public attitudes also favor regulations over carbon pricing policies, given the stigma associated with taxation and the growing concern about climate change (Nowlin et al., 2020). The lack of stringency in subnational carbon pricing policies and failure to implement one at the federal level has convinced many environmental groups that any carbon pricing legislation is unlikely to result in substantial emissions reduction because politically acceptable carbon prices are too low to seriously disincentivize carbon emissions
(Stokes \& Mildenberger, 2020) and any pricing policy is likely to include contemporaneous compensation of incumbent and/or EITE industries (Dolphin et al., 2020). Environmental organizations now tend to prefer regulatory approaches such as CES, which usually provide assurances that emissions will decrease. And, finally, environmental justice groups are concerned that a carbon price continues to allow polluters to pay a fee and pollute low-income communities without significant emission reductions.

\section{Concluding Remarks: Implications for Carbon Pricing in the US}

Prospects of an ambitious federal carbon pricing policy in the US appear bleak, given the contestations among industry groups and environmental organizations, the politicization of climate change, and public opinion strongly divided along partisan lines (Bryant, 2016; Nowlin et al., 2020). The urgent need to pursue deep decarbonization and reach net-zero GHG emissions by mid-century makes it unlikely that relying primarily on carbon pricing policies is a good strategy for climate advocates (Tvinnereim \& Mehling, 2018). As energy journalist David Roberts wrote in a New York Times Opinion article in July 2021, Congressional Democrats are determined to act rapidly and at a massive scale to avoid the worst consequences of climate change (Bokat-Lindell, 2021). Actions to date under the Biden administration likewise have avoided carbon pricing. First, the administration's press release on climate action on April 22, 2021 did not mention a carbon pricing policy (The White House, 2021). Second, the administration announced a social cost of carbon of $\$ 51$ per ton of carbon in regulatory policy, increasing it from the $\$ 1$ to $\$ 7$ per ton used by the Trump administration (Chemnick, 2021). The Biden administration wanted to show leadership before COP26 in Glasgow by passing a CES, which ultimately did not pass before the conference in November 2021 (Renshaw et al., 2021). While the CES is less cost-efficient than a carbon price, it is more targeted and was more likely to pass, given public support for regulatory approaches over tax policies (Leiserowitz et al., 2021). Given these developments, it is clear the Biden administration has sidelined, at least for now, the carbon tax proposals supported by several Democrats, Republicans, and industry interest groups, in favor of more stringent regulatory policies.

This article examined the politics of carbon pricing at the subnational and federal level in the US from the perspective of policy entrepreneurship and interest group politics. The politics of carbon pricing in the US is complicated by numerous diverse interest groups and greater public climate skepticism than in other parts of the world. The multiplicity of American interest groups and veto actors combined with the lack of effective policy entrepreneurship all make federal carbon pricing unlikely, but there is continued promise for carbon pricing at the subnational level. RGGI has managed to attract 
two more states, Virginia and Pennsylvania, to its capand-trade regime and is now exploring a cap-and-trade system for the transportation sector. California has managed to expand its emissions coverage, increase the percentage of auctioned allowances, and link with another cap-and-trade regime in Québec, Canada. On the other hand, the subnational trading regimes have struggled to increase their policy stringency due to political opposition, which has resulted in relatively low effective carbon prices and, in turn, relatively weak price incentives to reduce emissions. These weaknesses have led to growing disenchantment with carbon pricing among environmental advocates even while private sector actors increasingly embrace carbon pricing as a policy measure to decarbonize. American labor unions have consistently been ambivalent about carbon pricing but have embraced the idea of a just transition in the context of a Green New Deal. In conclusion, carbon pricing is likely to remain but one important policy tool of many others in the US and it is more likely that fiscal and regulatory policy tools will prevail at the federal level.

\section{Acknowledgments}

The authors would like to thank the anonymous reviewers and thematic issue editors for their valuable suggestions and comments. The authors thank the Science, Technology, and Public Policy Program at Harvard University and Climate Policy Lab at The Fletcher School, Tufts University for funding this project. The authors wish to gratefully acknowledge the financial support provided towards this article by the following past and present funders of the Climate Policy Lab: the William and Flora Hewlett Foundation, BP International, Ltd., and the Casey and Family Foundation.

\section{Conflict of Interests}

The authors declare no conflict of interests.

\section{Supplementary Material}

Supplementary material for this article is available online in the format provided by the author (unedited).

\section{References}

350.org. (2021, March 25). 350.org on American Petroleum Institute support for carbon pricing [Press Release]. https://350.org/press-release/apisupport-for-carbon-pricing

Aldy, J. E., \& Pizer, W. A. (2015). The competitiveness impacts of climate change mitigation policies. Journal of the Association of Environmental and Resource Economists, 2(4), 565-595.

American Federation of Labor and Congress of Industrial Organizations. (2009). Statement on behalf of the United Mine Workers of America, AFL-CIO before the
United States Senate. United States Senate. https:// www.epw.senate.gov/public/_cache/files/2e58d71fafb1-484b-a45d-5ac0bc1b9b15/umwasenateepw statement102909.pdf

Anderson, S. E., DeLeo, R. A., \& Taylor, K. (2020). Policy entrepreneurs, legislators, and agenda setting: Information and influence. Policy Studies Journal, 48(3), 587-611. https://doi.org/10.1111/psj.12331

Arrieta-Kenna, R. (2017, July 18). California just got bipartisan support to extend its cap and trade program to 2030. Vox. https://www.vox.com/energyand-environment/2017/7/15/15955756/californiaclimate-brown-ab398-cap-and-trade

Ball, M., \& Weeda, M. (2015). The hydrogen economyvision or reality? International Journal of Hydrogen Energy, 40(25), 7903-7919.

Bang, G., Victor, D. G., \& Andresen, S. (2017). California's cap-and-trade system: Diffusion and lessons. Global Environmental Politics, 17(3), 12-30.

Bausch, C., \& Cavalieri, S. (2007). Allocation of greenhouse gas allowances in the United States-A northeastern example. Carbon \& Climate Law Review, 2007(2), 129-138.

Bell, A., \& Mallinson, D. J. (2021). Constraints on policy learning: Designing the Regional Greenhouse Gas Initiative in Pennsylvania. Policy Design and Practice, 4(4), 486-500. https://doi.org/10.1080/25741292. 2021.1928970

Biedenkopf, K. (2017). Gubernatorial entrepreneurship and United States federal-state interaction: The case of subnational regional greenhouse gas emissions trading. Environment and Planning C: Politics and Space, 35(8), 1378-1400. https://doi.org/10.1177/ 2399654417719286

Bokat-Lindell, S. (2021, July 22). Opinion: Where Is Biden's climate change "revolution"? The New York Times. https://www.nytimes.com/2021/07/22/ opinion/biden-climate-change.html

Breetz, H. L., \& Salon, D. (2018). Do electric vehicles need subsidies? Ownership costs for conventional, hybrid, and electric vehicles in 14 US cities. Energy Policy, 120, 238-249.

Broder, J. M. (2009, July 1). With something for everyone, climate bill passed. The New York Times. https://www.nytimes.com/2009/07/01/us/politics/ 01climate.html

Broekhoff, D., Ulloa, S., \& Veysey, J. (2021). To decarbonize US industry, look to federal and state-level partnerships. Leadership Group for Industry Transition. https://www.industrytransition.org/insights/ decarbonize-us-industry-federal-state-levelpartnerships

Bryant, G. (2016). The politics of carbon market design: Rethinking the techno-politics and post-politics of climate change. Antipode, 48(4), 877-898. https://doi. org/10.1111/anti.12237

Bushnell, J., \& Chen, Y. (2012). Allocation and leakage in regional cap-and-trade markets for $\mathrm{CO} 2$. Resource 
and Energy Economics, 34(4), 647-668.

California Air Resources Board. (2019). California greenhouse gas emission for 2000 to 2017. https:// ww3.arb.ca.gov/cc/inventory/pubs/reports/2000_ 2016/ghg_inventory_trends_00-16.pdf

California Air Resources Board. (2021a). 2000-2019 GHG inventory. https://ww2.arb.ca.gov/ghg-inventorydata

California Air Resources Board. (2021b). Allowance allocation. https://ww2.arb.ca.gov/our-work/ programs/cap-and-trade-program/allowanceallocation

California Air Resources Board. (2021c). Summary of proceeds to California and consigning entities. https://ww2.arb.ca.gov/sites/default/files/202009/proceeds_summary.pdf

California Air Resources Board. (2021d). Detailed price ceiling sale requirements and instructions. https:// ww2.arb.ca.gov/sites/default/files/classic//cc/ capandtrade/pcs_requirements.pdf

California Air Resources Board. (2021e). Program linkage. https://ww2.arb.ca.gov/our-work/programs/capand-trade-program/program-linkage

California Case Chart. (2021). California Chamber of Commerce v. California Air Resources Board. http:// climatecasechart.com/climate-change-litigation/ case/california-chamber-of-commerce-v-californiaair-resources-board

California Climate Investments. (2019). California Climate Investments using cap-and-trade auction proceeds. https://ww2.arb.ca.gov/sites/default/ files/classic/cc/capandtrade/auctionproceeds/2019_ cci_annual_report.pdf

California Energy Commission. (2021). 2021 SB 100 joint agency report, achieving 100 percent clean electricity in California: An initial assessment. https://www. energy.ca.gov/publications/2021/2021-sb-100joint-agency-report-achieving-100-percent-cleanelectricity

California Environmental Justice Alliance. (2017). How California's cap and trade market undermines environmental justice. https://caleja.org/wp-content/ uploads/2017/05/REDDMonitor.050817.pdf

California Global Warming Solutions Act of 2006, Pub. L. No. AB 32. (2006). https://leginfo.legislature.ca.gov/ faces/billNavClient.xhtml?bill_id=200520060AB32

California Global Warming Solutions Act of 2006, Pub. L. No. AB 398. (2017). https://leginfo.legislature.ca. gov/faces/billTextClient.xhtml?bill_id=201720180AB 398

California Legislative Information. (2005). SB-1368 electricity: Emissions of greenhouse gases. https:// leginfo.legislature.ca.gov/faces/billNavClient.xhtml? bill id $=200520060$ SB1368

Cann, H. (2021, September 1). Pennsylvania takes the final step toward joining RGGI. City and State Pennsylvania. https://www.cityandstatepa.com/content/ pennsylvania-takes-final-step-toward-joining-rggi
Carbon Tax Center. (2018). Washington State (Initiative 1631). https://www.carbontax.org/washingtonstate-initiative-1631

Center for Climate and Energy Solutions. (2021, June 16). Regional Greenhouse Gas Initiative (RGGI). https:// www.c2es.org/content/regional-greenhouse-gasinitiative-rggi

Chemnick, J. (2021, March 1). Cost of carbon pollution pegged at $\$ 51$ a ton. Scientific American. https://www.scientificamerican.com/article/costof-carbon-pollution-pegged-at-51-a-ton

Climate Hawks. (2017). California: Broad coalition of environmental justice, climate groups oppose cap and trade bill. http://climatehawksvote.com/ news/press-releases/california-broad-coalitionenvironmental-justice-climate-groups-oppose-captrade-bill

Cook, B. J. (2010). Arenas of power in climate change policymaking. Policy Studies Journal, 38(3), 465-486. https://doi.org/10.1111/j.1541-0072.2010.00370.x

Cronin, J. A., Fullerton, D., \& Sexton, S. (2019). Vertical and horizontal redistributions from a carbon tax and rebate. Journal of the Association of Environmental and Resource Economists, 6(S1), S169-S208.

Davenport, C., \& Samuelsohn, D. (2010, July 22). Dems pull plug on climate bill. Politico. https://www. politico.com/story/2010/07/dems-pull-plug-onclimate-bill-040109

Dobson, S., \& Winter, J. (2018). Assessing policy support for emissions-intensive and trade-exposed industries. The School of Public Policy Publications, 11(28), 1-47.

Dolphin, G., Pollitt, M. G., \& Newbery, D. M. (2020). The political economy of carbon pricing: A panel analysis. Oxford Economic Papers, 72(2), 472-500.

Drew, A. J. (2010). New rules, new politics, same actorsExplaining policy change in the EU ETS (Working Paper No. 39). Grantham Research Institute on Climate Change and the Environment. https://www.Ise. ac.uk/granthaminstitute/wp-content/uploads/ 2014/02/WP29-policy-change-EU-ETS.pdf

Energy Information Administration. (2019). Total energy consumer per capita, 2019. https://www.eia.gov/ state/rankings

Environmental Protection Agency. (2019). 2019 power sector programs-Progress report. https://www3. epa.gov/airmarkets/progress/reports

Fischer, C., \& Fox, A. K. (2012). Climate policy and fiscal constraints: Do tax interactions outweigh carbon leakage? Energy Economics, 34, S218-\$227.

Google Trends. (n.d.). Google Trends. https://www. google.com/trends

Greenpeace. (2010, July 6). Greenpeace opposes Waxman-Markey. https://www.greenpeace.org/ usa/news/greenpeace-opposes-waxman-mark

Hafstead, M. (2021, June 21). Carbon pricing bill tracker. Resources for the Future. https://www.rff.org/ publications/data-tools/carbon-pricing-bill-tracker

Huber, B. R. (2013). How did RGGI do it: Political econ- 
omy and emissions auctions. Ecology Law Quarterly, 40(1), 59-106.

Ike, V. (2020). The impact of veto players on incremental and drastic policy making: Australia's carbon tax policy and its repeal. Politics \& Policy, 48(2), 232-264. https://doi.org/10.1111/polp.12346

International Carbon Action Partnership. (2021a). USARegional Greenhouse Gas Initiative (RGGI). https:// icapcarbonaction.com/en/?option=com_etsmap\& task=export\&format=pdf\&layout=list\&systems\%5B $\% 5 \mathrm{D}=50$

International Carbon Action Partnership. (2021b). USA-California Cap-and-Trade Program. https:// icapcarbonaction.com/en/?option=com_etsmap\& task=export\&format $=$ pdf\&layout=list\&systems\%5B $\% 5 \mathrm{D}=45$

Jenkins, J. D. (2014). Political economy constraints on carbon pricing policies: What are the implications for economic efficiency, environmental efficacy, and climate policy design? Energy Policy, 69, 467-477.

Jevnaker, T., \& Wettestad, J. (2017). Ratcheting up carbon trade: The politics of reforming EU Emissions trading. Global Environmental Politics, 17(2), 105-124. https://doi.org/10.1162/GLEP_a_00403

Kretzschmar, B., \& Whitford, A. B. (2012). Design, performance and interstate collaboration: Insights from the Regional Greenhouse Gas Initiative. Regional \& Federal Studies, 22(4), 475-498. https://doi.org/ 10.1080/13597566.2012.709503

Leiserowitz, A., Maibach, E., Rosenthal, S., Kotcher, J., Carman, J., Wang, X., Goldberg, M., Lacroix, K., \& Marlon, J. (2021). Politics \& global warming, December 2020. Center for Climate Change Communication, George Mason University. https://climate communication.yale.edu/wp-content/uploads/ 2021/01/politics-global-warming-december2020b.pdf

Lizza, R. (2010, October 3). As the world burns. The New Yorker. https://www.newyorker.com/magazine/ 2010/10/11/as-the-world-burns

Markard, J., \& Rosenbloom, D. (2020). Political conflict and climate policy: The European emissions trading system as a trojan horse for the low-carbon transition? Climate Policy, 20(9), 1092-1111. https://doi. org/10.1080/14693062.2020.1763901

Mason, M., \& Megerian, C. (2017, July 18). California legislature extends state's cap-and-trade program in rare bipartisan effort to address climate change. Los Angeles Times. https://www.latimes.com/politics/ la-pol-ca-california-climate-change-voterepublicans-20170717-story.html

McGreal, C. (2021, June 30). ExxonMobil lobbyists filmed saying oil giant's support for carbon tax a PR ploy. The Guardian. http://www.theguardian.com/usnews/2021/jun/30/exxonmobil-lobbyists-oil-giantcarbon-tax-pr-ploy

Meckling, J. (2011). Carbon coalitions: Business, climate politics, and the rise of emissions trading. MIT Press.
Meyer, A., \& Neuberger, J. (2021, April 12). Trade associations speak on carbon pricing. Will action follow? World Resources Institute. https://www.wri.org/ insights/trade-associations-speak-carbon-pricingwill-action-follow

Murray, B. C., \& Maniloff, P. T. (2015). Why have greenhouse emissions in RGGI states declined? An econometric attribution to economic, energy market, and policy factors. Energy Economics, 51, 581-589. https://doi.org/10.1016/j.eneco.2015.07.013

Narassimhan, E., Gallagher, K. S., Koester, S., \& Alejo, J. R. (2018). Carbon pricing in practice: A review of existing emissions trading systems. Climate Policy, 18(8), 967-991. https://doi.org/10.1080/14693062. 2018.1467827

National Association for the Advancement of Colored People. (2021). Nuts, bolts, and pitfalls of carbon pricing: An equity-based primer on paying to pollute. https://naacp.org/sites/default/files/ documents/Carbon\%20Pricing\%20Primer.pdf

Nowlin, M. C., Gupta, K., \& Ripberger, J. T. (2020). Revenue use and public support for a carbon tax. Environmental Research Letters, 15(8), Article 084032. https://doi.org/10.1088/1748-9326/ab92c3

Patashnik, E. M. (2014). Reforms at risk. What happens after major policy changes are enacted. Princeton University Press. https://www.degruyter.com/ document/doi/10.1515/9781400828852/html

Paterson, M. (2012). Who and what are carbon markets for? Politics and the development of climate policy. Climate Policy, 12(1), 82-97. https://doi.org/ 10.1080/14693062.2011.579259

Rabe, B. G. (2016). The durability of carbon cap-andtrade policy. Governance, 29(1), 103-119. https:// doi.org/10.1111/gove.12151

Ramseur, J. L. (2019). The Regional Greenhouse Gas Initiative: Background, impacts, and selected issues (Report No. R41836). Congressional Research Service. https://sgp.fas.org/crs/misc/R41836.pdf

Raymond, L. (2019). Policy perspective: Building political support for carbon pricing-Lessons from capand-trade policies. Energy Policy, 134, Article 110986. https://doi.org/10.1016/j.enpol.2019.110986

Reed, M., O'Reilly, P., \& Hall, J. (2019). The economics and politics of carbon taxes and regulations: Evidence from voting on Washington State's Initiative 732. Sustainability, 11(13), Article 3667.

Regional Greenhouse Gas Initiative. (2021a). A brief history of RGGI. https://www.rggi.org/programoverview-and-design/design-archive

Regional Greenhouse Gas Initiative. (2021b). The RGGI model rule. https://www.rggi.org/programoverview-and-design/design-archive/mou-modelrule

Regional Greenhouse Gas Initiative. (2021c). New Jersey participation. https://www.rggi.org/programoverview-and-design/design-archive/njparticipation 
Reilly, A., \& Bogardus, K. (2016, June 27). 7 years later, failed Waxman-Markey bill still makes waves. PoliticoPro. https://subscriber.politicopro.com/article/ eenews/1060039422

Renshaw, J., Mason, J., \& Gardner, T. (2021, October 20). U.S. Democrats scramble to hammer out climate legislation ahead of Glasgow talks. Reuters. https://www.reuters.com/world/us/us-democratsscramble-hammer-out-climate-legislation-aheadglasgow-talks-2021-10-20

Roberts, T. (2021, December 8). Who killed the TCl? Boston Globe. https://www.bostonglobe.com/2021/ 12/08/opinion/who-killed-tci

Schmalensee, R., \& Stavins, R. N. (2017). Lessons learned from three decades of experience with cap and trade. Review of Environmental Economics and Policy, 11(1), 59-79.

Skocpol, T. (2013, February 14). Naming the problem: What it will take to counter extremism and engage Americans in the fight against global warming [Paper presentation]. Symposium on The Politics of America's Fight Against Global Warming, Massachusetts, USA.

Skovgaard, J., Ferrari, S. S., \& Knaggård, Å. (2019). Mapping and clustering the adoption of carbon pricing policies: What polities price carbon and why? Climate Policy, 19(9), 1173-1185. https://doi.org/10.1080/ 14693062.2019.1641460

Stavins, R. N. (2008). Addressing climate change with a comprehensive US cap-and-trade system. Oxford Review of Economic Policy, 24(2), 298-321.

Steinebach, Y., Fernández-i-Marín, X., \& Aschenbrenner, C. (2021). Who puts a price on carbon, why and how? A global empirical analysis of carbon pricing policies. Climate Policy, 21(3), 277-289. https://doi.org/ 10.1080/14693062.2020.1824890

Stokes, L., \& Mildenberger, M. (2020, September 8). The trouble with carbon pricing. Boston Review. https://bostonreview.net/articles/leah-c-stokesmatto-mildenberger-tk

The White House. (2021, April 22). President Biden sets 2030 greenhouse gas pollution reduction target. https://www.whitehouse.gov/briefing-room/ statements-releases/2021/04/22/fact-sheetpresident-biden-sets-2030-greenhouse-gaspollution-reduction-target-aimed-at-creating-goodpaying-union-jobs-and-securing-u-s-leadership-on- clean-energy-technologies

Tvinnereim, E., \& Mehling, M. (2018). Carbon pricing and deep decarbonisation. Energy Policy, 121, 185-189.

Union of Concerned Scientists. (2013). Assessing trade and business groups' positions on climate change. https://www.ucsusa.org/sites/default/files/201909/trade-and-business-groups-climate-change.pdf

US House of Representatives. (1990). H.R.4805-To amend the Internal Revenue Code of 1986 to reduce emissions of carbon dioxide by imposing a tax on certain fuels based on their carbon content. https:// www.congress.gov/bill/101st-congress/housebill/4805

US House of Representatives. (2019). H.Res.109Recognizing the duty of the Federal Government to create a Green New Deal. https://www.congress. gov/bill/116th-congress/house-resolution/109

US Justice Department. (2019). The United States of America v. The State of California. https://www. justice.gov/opa/press-release/file/1212416/ download

US Justice Department. (2020). The United States of America v. The State of California-Memorandum and order. http://blogs2.law.columbia.edu/climatechange-litigation/wp-content/uploads/sites/16/ case-documents/2020/20200312_docket-219-cv02142_memorandum-and-order.pdf

Venmans, F., Ellis, J., \& Nachtigall, D. (2020). Carbon pricing and competitiveness: Are they at odds? Climate Policy, 20(9), 1070-1091. https://doi.org/10.1080/ 14693062.2020.1805291

Weiss, D. J., \& Wagener, D. (2009, May 18). 10 reasons to support the Waxman-Markey energy bill. Center for American Progress Action. https://www. americanprogressaction.org/issues/green/news/ 2009/05/18/6143/10-reasons-to-support-thewaxman-markey-energy-bill

Wessel, D. (2009, May 24). Pollution politics and the Climate-Bill giveaway. Wall Street Journal. https:// www.wsj.com/articles/SB124304449649349403

Wettestad, J., \& Gulbrandsen, L. H. (2017). The evolution of carbon markets: Design and diffusion. Routledge.

Wilson, J. Q. (1980). The politics of regulation. Routledge.

World Bank. (2021). State and trends of carbon pricing 2021. https://openknowledge.worldbank.org/ handle/10986/35620

\section{About the Authors}

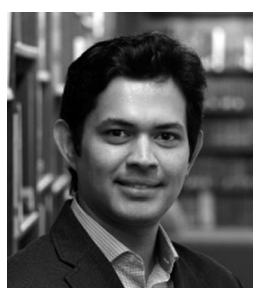

Easwaran Narassimhan is a post-doctoral fellow at Harvard University's Belfer Center for Science and International Affairs and the Climate Policy Lab at the Fletcher School at Tufts University. His research focuses on the political economy of green transitions, with a particular interest in exploring opportunities and challenges for industrialization and economic development in a climate constrained world. 


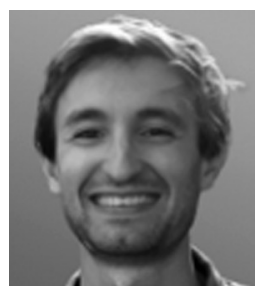

Stefan Koester is a senior policy analyst focused on clean energy innovation technologies and climate change policy. He has a background in energy and environmental policy and has worked on carbon pricing, corporate sustainability, energy efficiency, electricity markets, and issues related to the electric power sector and renewable energy at the state, regional, and federal levels.

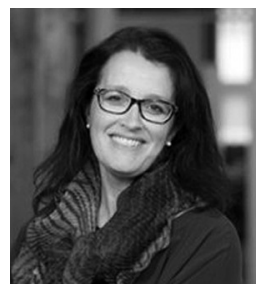

Kelly Sims Gallagher is the academic dean and professor of energy and environmental policy at The Fletcher School, Tufts University. She directs the Climate Policy Lab and the Center for International Environment and Resource Policy at Fletcher. She served in the second term of the Obama Administration as a senior policy advisor in the White House Office of Science and Technology Policy, and as senior China advisor in the Special Envoy for Climate Change office at the US State Department. Gallagher focuses on energy innovation and climate policy, focusing on how policy spurs the development and deployment of cleaner and more efficient energy technologies, domestically and internationally. 